\title{
Public and Private Investment and Economic Growth in Namibia (1970-2005)
}

\author{
Festus Tangeni KANDENGE ${ }^{1}$
}

\begin{abstract}
Using the framework of an endogenous growth model, this study analyzes the impact of public and private investment on economic growth in Namibia over the 1970-2005 periods. Cointegration and error correction modeling approaches were adopted. The results suggest that in addition to public and private investment,-exports, imports, economic freedom, labour and human capital significantly and positively impact on short and long-term economic growth. In contrast, terms of trade and real exchange rate, are found to have a negative effect on short and long-term economic growth. The short-term dynamic behaviour of this relationship was investigated by estimating an error correction model. The error correction term was found to be statistically significant and with correct sign.
\end{abstract}

\subsection{Introduction}

The impact of public and private investment on economic growth, is a long-standing issue in macroeconomics and development economics, and has attracted renewed attention in recent years. Two factors are behind this resurgence. On the one hand, the worldwide shift towards a growth strategy underscoring market forces and private sector leadership prior to the ongoing global financial and economic crisis led to a curtailment of the public sector from production and to a redefinition of its role in the development process in many countries, under the guiding principle that the public sector should concentrate its resources in areas where it supports, rather than crowd out the private sector [see, Luis (1996)]. In academic cycles, on the other hand, the macroeconomic impact of public and private investment on economic growth was brought to centre stage by Aschauer (1989a, b), who analyzed, empirically, the impact of public capital accumulation on US private investment and output, and found a sizable positive effect in both cases. Aschauer's work was quickly followed by a rapidly growing literature re-examining his results - which remain controversial - from both micro and macroeconomic perspectives [see, Gramlich (1994) for extensive review] and an extension of his analysis to other countries [e.g., Berndt and Hansson (1992), Argimon et. al. (1995)].

Following this tradition, this study examines empirically the impact of public and private investment on economic growth in Namibia. In the context of a state-led, inward oriented development strategy that started in the early 1970's, Namibia public enterprises extended into virtually all sectors of the economy. Moreover, public enterprises were instrumental in generating increasingly large public investment and eventually led to a radical reorientation of economic policy. From the policy viewpoint, the need for a substantial curtailment of the public sector in Namibia has underscored the importance of redefining public investment priorities in favour of those activities supportive of rapid private sector expansion. Therefore, the objective of the study is to investigate how public and private investments affect economic growth in Namibia. It also appraises the distinction between the impacts of private and public investment on economic growth in Namibia. The study adopted an approach suggested by Khan and Reinhart (1990) and Nazmi and Ramirez (1997 and 2003). It revisits empirically the impact of public and private investment on economic growth. The study develops a simple analytical model embodying the distinction between public and private investment, and implements it using aggregate public and private investment data for Namibia. The rest of the study is arranged as

\footnotetext{
${ }^{1}$ University of Namibia. Email: fkadenge@unam.na; tangeni2004@yahoo.com
} 
follows, section two discusses economic growth, public and private investment in Namibia, section three presents a review of the relevant literature, and section four discusses the methodology. The empirical results are presented in section five and section six concludes summary of finds, recommendation and conclusion. Due to lack of comparable data for recent years, the scope of the study is limited to the period 1970 to 2005.

\subsection{Economic Growth, Public and Private Investment Performance in Namibia}

Since 1971 the growth performance of Namibia has been relatively impressive (see, Figure 2.1). The average annual growth rate of the economy was 3.5 percent over the years 1971 to 2005 . During 1971 to 1981 period, the economy recorded a positive average growth rate of 3.0 percent, while the ratios of public and private investment to GDP were 14 percent respectively. However, the slowdown of the global economy in the early 1980's culminated in negative average growth rate of the economy, thus during 1982 to 1984 period, Namibia witnessed a reduction in the real GDP growth rate by -1.4 percent annually and the ratio of public and private investment to GDP was a cumulative 13.2 percent and 7.2 percent on average respectively. In subsequent years however, specifically during the 1985 to 1989 period, the economy bounced back, registering a positive average growth of 4.2 percent. The ratios of private and public investment to GDP were 7.8 percent and 7.5 percent respectively.

The growth performance during the post-independence period has also been relatively impressive. The average annual growth rate of the economy was 4.3 percent over the years 1990 to 2005. During this period of high economic performance, the government's roles in the economy were characterized by various phases of involvement. After independence, Namibia inherited a laissez faire type economic system, which gave the private sector a leading role in the nation's development process. The government largely played supplementary roles to the private sector by directing public expenditures toward providing basic and necessary infrastructure.

\section{Figure 2.1: GDP Growth, Public and Private Investment as percentage of GDP}

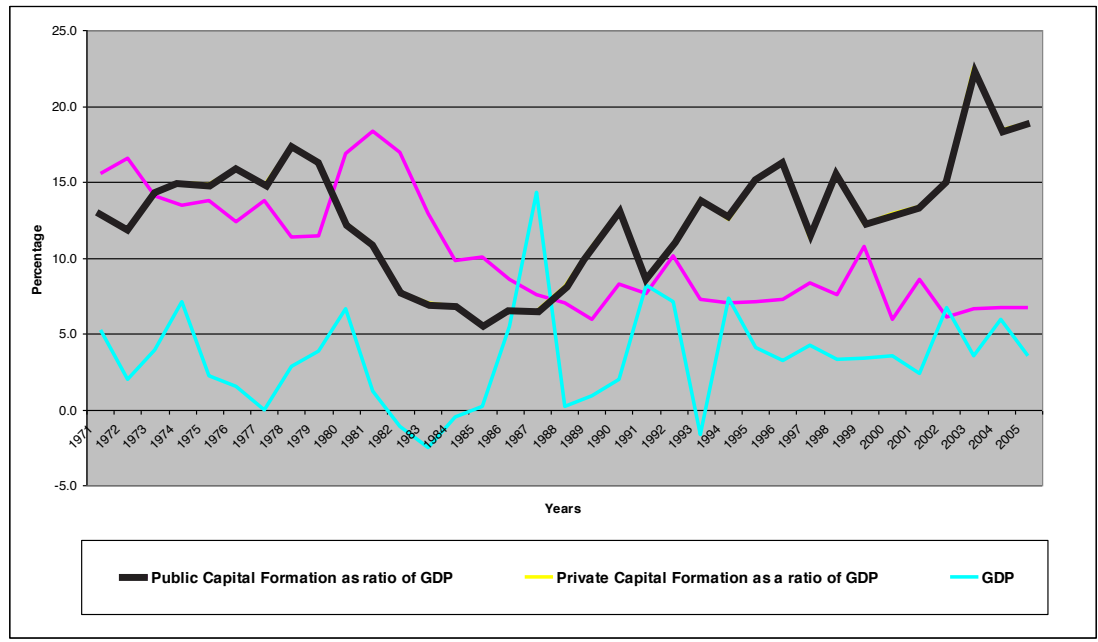

Sources: United Nation Common Database 1971-2005

During this early period, the government also implemented policies to diversify the economic base of the country, which mainly depended on mineral resource and agricultural production. Moreover, economic stability was at the forefront of the government's economic agenda, as it was highly important for the economy to grow without interruptions. Economic performance during the period of 1991-1996 was hugely successful as the economy recorded an average growth rate of 5.0 percent. Public investment ratio to GDP during the same period was 5.2 percent on average, while the private investment ratio to GDP was 12.7 percent (see, Figure 2.1). 
At the same time, however, the economy was confronted with enormous development challenges, necessitating a change in orientation marked by the formal adoption of development plans. The government introduced and implemented national development plans in order to address the following; reviving and sustaining economic growth, creating employment, reducing inequalities in income distribution and eradicating poverty. As the government made clear, the mechanism to achieve these four objectives is through high economic growth. The national development plans also marked the beginning of active government involvement in the economy. Subsequently, the ratio of the public capital formation to GDP increased to 7.8 percent average during 1991-1996 period from 7.5 percent average during the 1986-1990 period. A more pronounced increase was observed, however, in private investment ratio to GDP. It went up from 9.0 percent on average per year to 12.2 percent during the same period.

The average growth rate of the economy increased from 3.5 percent from 1996-2000 to 4.4 percent in 2001-2005. From 1996-2000, public investment ratio to GDP stayed at 8.0 percent annually and private investment ratio to GDP was 13.6 percent. The rate reassuring shows the continuing active participation of the public sector in the economy during the post-independence era. However during the 2001-2005 period, the ratio of public investment to GDP decreased to 6.9 percent mainly because the government embarked on a divestiture and private equity participation in public enterprises programme, in 2001, to relieve the financial and administrative burden of the government as well as to give greater roles to the private sector in the nation's development process. This resulted in private investment ratio of GDP at 17.7 percent during the same period.

\subsection{Literature Review}

Empirical studies on the relationship between public and private investments and economic growth are quite extensive. Much of the research was stimulated by Eberts (1986), Aschauer (1989a, 1989b) and Munnell (1990) empirical studies on the relationship between government investments on economic infrastructure, and economic growth at national, regional and state levels.

These studies (Aschauer (1989a), Eberts (1986), and Munnell (1990)) all found a statistically significant positive relationship between public investment and economic growth. These studies sparked up remarkable interest. Subsequent empirical studies conducted in this area, either using a single-equation time series of the type adopted by Aschauer (1989a) or a cross-section analysis (Easterly and Rebelo 1993) mostly indicated a positive effect of public investment on growth.

The role of public capital spending, especially, public infrastructural investment has also been theoretically considered in a production function framework (Aschauer 1989a) and endogenous growth theory, Barro (1989 and 1990). Not surprisingly, these studies have been widely criticized both methodologically and in the inference drawn. Charles and Peterson (1984) for example, emphasized that the reported relationship may not mean causality. In addition, Aschauer (1989a) and Munnell (1990) findings were criticized by Tatom (1991) as being spurious as they did not account for stochastic trends in the data. In his analysis, he subjected the data to standard unit root tests and found them to be non-stationary. He then used the first differences of the variables to estimate the production function and concluded that the strong positive association between private output and public capital disappeared. MacMillan and Smyth (1994) estimated the VAR models using both levels and first differences of the variables; they also concluded and indicated negligible impacts of public capital on output.

Concurringly, Munnell (1992) maintained that using only the first differences of the variables may lead to misspecification bias since first differencing filters out the long run information in the data. He critically examined the literature and postulated that future research should give particular attention to the integration and cointegration properties of the variables. Raymond (1998) reexamined the issue using annual observations in United States data from 1948 to 1993. Employing both integration and cointegration tests, he concluded that public 
capital seemed positively related to output, labour and private capital in the long run. The results also suggested and inferred that innovations in public capital could have long-lasting effects.

Public capital responded positively to innovations in output, labour and private capital. Devarajan et al. (1996) raised the possibility that public expenditures such as capital investments that were generally viewed as productive might be unproductive. Distinguishing between productive and unproductive expenditures, they showed that the effects on growth of the shift in their respective shares in the expenditures depended not only on the productivity of the two expenditures but also on their initial shares. Thus, the increase in productive public expenditure might be unproductive if its initial share is already excessive. This implication was supported by data from 43 developing countries over 20 years. Namely, the relationship between capital expenditure and growth per capita was found to be negative while that between current expenditure and growth was positive. These results led them to conclude that governments of developing countries tended to "over-invest" in public capital.

Aschauer (1989a) fitted an aggregate growth regression for the United States using annual data for the period 1949 to 1985; concluded that public capital was significantly productive and noted that the productivity of public capital exceeded that of private capital during the period. At the same time, Aschauer (1989b) documented highly positive and significant contributions of public net investments to the growth rates using a pooled data set of the Group of Seven industrial countries over the period 1966-1985 Aschauer (1989b). Moreover, Munnell (1990) further substantiated the findings of high contributions of public capital. Employing crossnational data, Barro (1989, 1990), and Khan and Kumar (1997) also found some evidence for a positive relationship between public investments and output growth.

Other empirical studies found positive effects of public capital spending, particularly infrastructural spending, on private investment, productivity and growth [see,Pereira (2000, 2001a and 2001b); and Mittnik and Neumann (2001)]. These studies suggest that a decrease in public capital spending could be harmful for economic growth. Currently there are two related strands of research on the role of public capital spending in capital accumulation and economic growth. The first one focuses on the public investment spending and private investment nexus.

In this research area, many studies found significant complementarity's crowding-in effect, but some studies found inconclusive or contradictory results Argimon et al. (1997); Cardosa (1993); Aschauer (1989b), among others suggest that this ambiguity might be the result of using aggregate rather than disaggregate public investment, e.g. infrastructural public investment. Mustafa et al. (2002) found some evidence of crowding-out effect of total public investment on private investment; there was no significant effect of public infrastructural investment on private investment in the long-run. However, they found some evidence of complementarities between private and public investment over the short and medium-run. Their results suggest that the chronic macroeconomic instability seems to become a serious impediment to the public investment, and has shattered, or even reversed, the long-run complementarities.

Nazmi and Ramirez (1997) analyzed the impact on economic growth of public and private investment spending. They concluded that public investment expenditures had a positive and significant effect on output growth. At the same time public investment's impact on economic growth was statistically identical to the impact of private capital spending. The contribution of public investment to output expansion however came at the expense of private investment as indicating a significant crowding out effect. Using cross country data, Easterly and Rebelo (1993) find a positive effect of investment in transport and communication on economic growth. Canning et al. (1994) found positive effect of telephones on economic growth, while Sanchez (1998) also find a positive impact of road length and electricity generating capacity in explaining subsequent economic growth. In contrast, Tatom (1991, 1993a, 1993b) and HoltzEakin (1993 and 1994), and Holtz and Schwartz (1995) suggest that there is little evidence of an effect from infrastructure to income growth in a panel of U.S. state level data, particularly when fixed effects are included. 
Fan et al. (2004) using regional-level data for 1977-1999, the study developed a conceptual framework and model to estimate effects of different types of government expenditure on agricultural growth and rural poverty in rural Thailand. The results show that most government investments such as agricultural Research and Development, irrigation, rural education, and infrastructure including roads and electricity, had positive impacts on agricultural productivity growth and rural poverty reduction. However, variations in their marginal effects on production and poverty reduction were large, among different types of spending and across regions.

In conclusion public investment in physical capital for instance is far more important for macroeconomic performance than public consumption. Apart from the direct multiplier effect, resulting from all types of government expenditures, public infrastructures are an important input in the private sector production process, affecting both output and productivity. They not only enlarge the capital stock of a nation but also enable a more efficient use of the existing stock. Intuitively, firms simply cannot operate without having an extended system of highways, airports, communication networks, electrical and gas facilities, sewers and other components of public infrastructure at their disposal. Not only the existence but also the quality of the infrastructure is an important element. A highway in bad condition for instance increases the wear on trucks and the time spent driving, resulting in a lower productivity of both private capital and labor Munnell (1990a).

\subsection{Theoretical Framework and Model Specification}

The neoclassical growth model framework of Solow (1956) has been adopted in this study. The model has been used extensively by, among others, Ram (1978), Khan and Reinhart (1990) and Nazmi and Ramirez (1997 and 2003) to determine the impact of public and private investment on long-term economic growth in developing country. The framework of the growth model take as its starting point an aggregated production function of Cobb-Douglas function which related to output to factors inputs and variable referred to as total factor productivity.

\section{$y=A f(K, L, Z)$}

where $y$ is the level of output, $K$ is the stock of physical capital, $L$ is labor force, and $Z$ is the vector including other factors affecting growth. The variable $A$ measures the factor of productivity, which is generally assumed to be an exogenous rate. The sign of partial derivative of $y$ with respect to the argument in $f(\bullet)$ as well as $A$ are assumed to be positive. Expressing equation (1.4.1) in growth terms we obtain

$$
\frac{d y}{y}=\left[A \bullet \frac{\partial y}{K}\right] \frac{d K}{y}+\left[A \bullet \frac{\partial y}{\partial L} \bullet \frac{L}{y}\right] \frac{d L}{L}+\left[A \bullet \frac{\partial y}{\partial Z} \bullet \frac{Z}{y}\right] \frac{d Z}{Z}+\frac{d A}{A}
$$

which can be rewritten for estimation purposes as;

$$
\frac{\Delta y}{y}=\alpha_{0}+\alpha_{1} \frac{I}{y_{t-1}}+\alpha_{2} \frac{\Delta L}{L_{t-1}}+\alpha_{3} \frac{\Delta Z}{Z_{t-1}}
$$

where;

$\boldsymbol{\alpha}_{o}=\frac{\boldsymbol{d} \boldsymbol{A}}{\boldsymbol{A}}$, the constant term is assumed to capture the growth of productivity; 
$\boldsymbol{\alpha}_{1}=\boldsymbol{A} \bullet \frac{\partial \boldsymbol{y}}{\partial K}$, is the marginal productivity of capital,

$\boldsymbol{\alpha}_{2}=A \bullet \frac{\partial y}{\partial L} \bullet \frac{L}{y}$, is the elasticity of output with respect to labor,

$\alpha_{3}=A \bullet \frac{\partial y}{\partial Z} \bullet \frac{Z}{y}$, is the elasticity of output with respect to other factors,

and $\boldsymbol{I}=\boldsymbol{d} \boldsymbol{K}$.

The term $\left(\boldsymbol{\alpha}_{0}\right)$ is assumed to capture the growth in productivity; $\left(\boldsymbol{\alpha}_{\mathbf{1}}\right)$ is the marginal productivity of capital, $\left(\boldsymbol{\alpha}_{2}\right)$ is the elasticity of output with respect to labor; and $\left(\boldsymbol{\alpha}_{3}\right)$ is the elasticity of output with respect to other factors. The equation (4.3) has been used in many research related to growth process in developing countries. To obtain the standard two-factor model involving only capital and labor one would set $\boldsymbol{\alpha}_{0}=\boldsymbol{\alpha}_{2}=\boldsymbol{\alpha}_{3}=\boldsymbol{0}$. The result is the familiar "incremental capital output ratio" relationship (ICOR) associated with among others, Chenery and Strout (1966). The more general specification of equation (4.3) is now the most popular, with various other determinants of growth introduced in addition to capital, labor, and productivity growth.

However, Khan and Reinhard (1990) emphasized one disadvantage of the model from the point of view of the new market based development and growth analysis. It tell us little about the independent effects of private and public investments on growth. Since the effects are combined into a single total investment variable, it is obviously not possible to ascertain whether an increase in private investment matched by a cut in public investment will assist or hinder the rate of growth of output. In order to test whether private sector investment and public sector investment have differential impact on the growth rate, one can split these up and rewrite equation (4.3) as:

$$
\frac{\Delta y}{y}=\beta_{0}+\beta_{1} \frac{I^{p}}{y_{t-1}}+\beta_{2} \frac{I^{g}}{y_{t-1}}+\beta_{3} \frac{\Delta L}{L_{t-1}}+\beta_{4} \frac{\Delta Z}{Z_{t-1}}
$$

Where $\boldsymbol{I}^{\boldsymbol{p}}$ is private sector investment and $\boldsymbol{I}^{\boldsymbol{g}}$ public sector investment, $\boldsymbol{I}^{\boldsymbol{p}}+\boldsymbol{I}^{\boldsymbol{g}}=\boldsymbol{I}$. If the effects on growth of private sector investment and public sector investment are the same, this would imply that the respective marginal productivities are equal $\boldsymbol{\beta}_{1}=\boldsymbol{\beta}_{2}$. On the other had if private investment is more efficient and productive at the margin than is the public sector investment, as argue by the proponents market based reforms, then we would expect $\boldsymbol{\beta}_{\mathbf{1}}>\boldsymbol{\beta}_{\mathbf{2}}$.

Moreover, Khan and Reinhard (1990) caution against forming conclusion about the respective roles of private and public investment on the basis of the relative size of the coefficient $\boldsymbol{\beta}_{\mathbf{1}}$ and $\boldsymbol{\beta}_{\mathbf{2}}$. This is because it is well known that private and public investments are related in developing countries although there is some certainty about whether on balance public sector investment increase or lower private sector investment. The concern is solely with the investment growth relationship thus needed to be indifferent about the fourth determinant of the growth in equation (4.4). Specifying the production function in log-linear form with an error term $u_{t}$ the following equation is written including other variables;

$$
\begin{aligned}
& \text { LGDP }=\beta_{0}+\beta_{1} L P U B+\beta_{2} L P R I V+\beta_{3} L L A B O U R+\beta_{4} L E X P O R T S+\beta_{5} \text { LIMPORTS }+\beta_{6} L T O T \\
& +\beta_{7} L E F+\beta_{8} L H U M+\beta_{9} L E X C H+u_{t}
\end{aligned}
$$

It is expect that the elasticity parameters. $\left(\boldsymbol{\beta}_{1}, \boldsymbol{\beta}_{2}, \boldsymbol{\beta}_{3}, \boldsymbol{\beta}_{4}, \boldsymbol{\beta}_{5}, \boldsymbol{\beta}_{6}, \boldsymbol{\beta}_{7}, \boldsymbol{\beta}_{8}, \boldsymbol{\beta}_{9}\right)>\mathbf{0}$ 
This lead to the specification of a general error correction model (ECM) (4.6) of the aggregated production function of the following form

$\Delta L G D P_{t} \equiv \beta_{0}+\beta_{1 i} \sum_{i=3}^{n} \Delta L P U B_{t-i}+\beta_{2 i} \sum_{i=3}^{n} \Delta L P R I V_{t-i}+\beta_{3 i} \sum_{i=3}^{n} \Delta L L A B O U R_{t-i}+\beta_{4 i} \sum_{i=3}^{n} \Delta$ LEXPORTS $_{t-i}$
$+\beta_{5 i} \sum_{i=3}^{n} \Delta$ IIMPORTS $_{t-i}+\beta_{6 i} \sum_{i=3}^{n} \Delta L T O T_{t-i}+\beta_{7 i} \sum_{i=3}^{n} \Delta L E F_{t-i}+\beta_{8 i} \sum_{i=3}^{n} \Delta L H U M_{t-i}+\beta_{9 i} \sum_{i=3}^{n} \Delta L E X C H+\beta_{10} E C_{t-1}$ (4.6)

Where $\boldsymbol{E C}_{\boldsymbol{t - 1}}$ is the error correction lag one time.

\subsection{Empirical Implementation and Analysis}

\subsection{Data}

For the empirical implementation the annual data on the macroeconomic variables of Namibia for the period 1970 to 2005 were utilized in this study. All the variables are transformed into natural log before estimation. The data is derived from various sources. Data for real GDP (LGDP), volume of exports of goods and services (LEXPORTS), volume of imports of goods and services (LIMPORTS), real exchange rate (LEXCH), real public (LPUB) and private investments (LPRIV), terms of trade (LTOT), human resources (LHUM), and labour (LLABOUR) were derived from the United Nations Common Database. All the macroeconomic variables data are in 1990 constant prices. Economic freedom (LEF) data is derived from The Fraser Institute database.

\subsection{Testing for Stationarity}

Unit Roots tests were conducted by utilizing the Augmented Dickey-Fuller (ADF) and PhillipPerron (PP) tests. The time series variables are in log form; LGDP, LEXPORTS, LIMPORTS, LEXCH, LPUB, LPRIV, LTOT, LHUM, LLABOUR and LEF. They were tested whether they are integrated of order one. The underlying models include a constant and time trend. The essence of the Augmented Dickey-Fuller (ADF) and Phillip-Perron (PP) tests is to verify the null hypothesis of non-stationarity, the rejection of which requires a negative and significant test statistic. The optimal lag length of the lagged differences of the tested variable is determined by minimizing the Akaike Information Criteria (AIC) and Schwarz Bastian Criteria (SBIC).

Table 5.1: Unit Roots Testing Results

\begin{tabular}{|c|c|c|c|c|c|c|c|c|}
\hline \multirow{3}{*}{$\begin{array}{c}\text { Macro } \\
\text { Variables }\end{array}$} & \multicolumn{4}{|c|}{ Augmented Dickey Fuller Test } & \multicolumn{4}{|c|}{ Phillips Perron Test } \\
\hline & \multicolumn{2}{|c|}{ ADF Level } & \multicolumn{2}{|c|}{$\begin{array}{l}\text { ADF First } \\
\text { Difference }\end{array}$} & \multicolumn{2}{|c|}{ PP Level } & \multicolumn{2}{|c|}{ PP First Difference } \\
\hline & $\tau_{u}$ & $\tau_{t}$ & $\tau_{u}$ & $\tau_{t}$ & $\tau_{u}$ & $\tau_{t}$ & $\tau_{u}$ & $\tau_{t}$ \\
\hline LGDP & 0.658 & -1.443 & $-5.105^{\mathrm{a}}$ & $-5.203^{a}$ & 1.378 & -1.351 & $-5.115^{\mathrm{a}}$ & $-8.519^{a}$ \\
\hline LIMPORTS & -0.746 & -1.770 & $-5.015^{\mathrm{a}}$ & $-4.940^{a}$ & -0.724 & -1.927 & $-4.968^{a}$ & $-4.883^{\mathrm{a}}$ \\
\hline LEXPORTS & -0.910 & -3.880 & $-5.426^{a}$ & $-5.334^{a}$ & -0.485 & -2.863 & $-10.116^{a}$ & $-9.817^{\mathrm{a}}$ \\
\hline LPUB & -3.643 & -3.663 & $-9.844^{\mathrm{a}}$ & $-4.960^{\mathrm{a}}$ & -3.694 & -3.730 & $-9.781^{\mathrm{a}}$ & $-9.675^{a}$ \\
\hline LPRIV & -1.273 & -1.944 & $-7.168^{a}$ & $-7.188^{a}$ & -1.255 & -1.957 & $-7.147^{\mathrm{a}}$ & $-7.188^{a}$ \\
\hline LEF & -1.310 & -1.864 & $-6.061^{a}$ & $-6.091^{a}$ & -1.302 & -1.846 & $-6.061^{\mathrm{a}}$ & $-6.092^{\mathrm{a}}$ \\
\hline LHUM & 0.625 & -2.121 & $-5.451^{a}$ & $-5.494^{a}$ & 0.637 & -2.101 & $-5.446^{\mathrm{a}}$ & $-5.483^{\mathrm{a}}$ \\
\hline LLABOUR & -0.869 & -2.300 & $-3.965^{\mathrm{a}}$ & $-3.957^{a}$ & -0.506 & -1.539 & $-4.173^{\mathrm{a}}$ & $-4.140^{\mathrm{a}}$ \\
\hline LEXCH & -0.438 & -3.036 & $-4.369^{a}$ & $-4.294^{a}$ & -0.495 & -2.445 & $-4.261^{a}$ & $-4.178^{\mathrm{a}}$ \\
\hline LTOT & -2.593 & -2.694 & $-6.070^{a}$ & $-5.988^{a}$ & -2.545 & -2.684 & $-8.408^{a}$ & $-10.446^{a}$ \\
\hline
\end{tabular}

Notes: $\tau_{u}$ intercept in the model, $\tau_{t}$ trend and intercept in the model.

${ }^{\text {a }}$ significant at $1 \%$. 
Each variable was examined to determine if it is stationary or non-stationary employing the unit roots test. If a time series is found to be non-stationary, subsequently tests were conducted to determine if its first difference is stationary. Using this procedure the order of integration of a time series is determined. Table 5.1 presents the results of Augmented Dickey-Fuller (ADF) and Phillip-Perron (PP) tests statistics for the log levels and the first differences of the logs of the annual time series data for Namibia for the period 1970 to 2005. From Table 5.1 it is evident that all-time series are integrated of the order of one in the first differences based on the Augmented Dickey-Fuller (ADF) and Phillip-Perron (PP) tests. The results are compatible with the hypothesis that stationarity characterizes the variables in this study.

\subsection{Testing for Co-integration}

According to Cengiz and Dilip (2005), the relations between the variables play a significant and important role in economic analysis. In the short-run, the variables may drift apart. But in the long-run, they converge to equilibrium. The cointegration analysis provides an analytical instrument in this process. As defined by Engle and Granger (1987), the stationarity of a variable determines the degree of integration of the variable. Engle and Granger (1987) have demonstrated that the linear combination is integrated at any order less than $d$, then these variable are integrated.

Table 5.2: Co-integration Results

\begin{tabular}{|c|c|c|c|c|c|c|c|}
\hline \multicolumn{4}{|c|}{ Trace Statistic } & \multicolumn{4}{|c|}{ Maximum Eigenvalue Test } \\
\hline Null & Alternative & $\begin{array}{c}\text { Trace } \\
\text { Statistic }\end{array}$ & $\begin{array}{c}\text { 95\% Critical } \\
\text { Value }\end{array}$ & Null & Alternative & $\begin{array}{c}\text { Maximum } \\
\text { Eigenvalue } \\
\text { Test }\end{array}$ & $\begin{array}{c}95 \% \\
\text { Critical } \\
\text { Value }\end{array}$ \\
\hline$r=0$ & $r=1$ & $446.132^{b}$ & $239.235^{b}$ & $r=0$ & $r=1$ & $18.448^{\mathrm{b}}$ & $64.505^{b}$ \\
\hline $\mathrm{r} \leq 1$ & $r=2$ & $327.684^{b}$ & $197.371^{\mathrm{b}}$ & $\mathrm{r} \leq 1$ & $r=2$ & $83.870^{\mathrm{b}}$ & $58.434^{b}$ \\
\hline $\mathrm{r} \leq 2$ & $r=3$ & $243.814^{b}$ & $159.530^{\mathrm{b}}$ & $r \leq 2$ & $r=3$ & $76.559^{b}$ & $52.363^{b}$ \\
\hline $\mathrm{r} \leq 3$ & $r=4$ & $167.255^{b}$ & $125.615^{b}$ & $r \leq 3$ & $r=4$ & $56.743^{b}$ & $46.231^{b}$ \\
\hline $\mathrm{r} \leq 4$ & $r=5$ & $110.512^{b}$ & $95.754^{\mathrm{b}}$ & $r \leq 4$ & $r=5$ & $43.544^{\mathrm{b}}$ & $40.078^{b}$ \\
\hline $\mathrm{r} \leq 5$ & $r=6$ & 66.968 & 69.819 & $r \leq 5$ & $r=6$ & 24.945 & 33.877 \\
\hline $\mathrm{r} \leq 6$ & $\mathrm{r}=7$ & 42.024 & 47.856 & $\mathrm{r} \leq 6$ & $r=7$ & 21.160 & 27.584 \\
\hline $\mathrm{r} \leq 7$ & $r=8$ & 20.864 & 29.797 & $\mathrm{r} \leq 7$ & $r=8$ & 11.851 & 21.132 \\
\hline $\mathrm{r} \leq 8$ & $r=9$ & 9.013 & 15.495 & $\mathrm{r} \leq 8$ & $r=9$ & 9.010 & 14.265 \\
\hline $\mathrm{r} \leq 9$ & $r=10$ & 0.003 & 3.841 & $r \leq 9$ & $r=10$ & 0.003 & 3.841 \\
\hline
\end{tabular}

Note: $r$ is the number of cointegrating vectors; ${ }^{b}$ means significance at $5 \%$ level.

The residual from the ordinary least squires (OLS) regression is usually taken as a proxy for the linear combination in the empirical analysis. For example the variables in the regression equation which has the same integration degree $[I(1)]$, will be co-integrated and have a steady state relationship, if and only if the residual of the OLS regression has the integration degree $I(0)$. When it is satisfied, the short-run equation can be constructed by using the error correction model (ECM) in order to achieve long-run equilibrium.

Table 5.2 present the Johansen's co integration tests. The results confirm evidence for the existence of a long-run relationship (i.e., co-integration) between LGDP, LEXPORTS, LIMPORTS, LEXCH, LPUB, LPRIV, LTOT, LHUM, LLABOUR and LEF. The null hypothesis for zero co-integrating vectors is rejected at the 5 percent significant level by the Trace Test and at 5 percent significant level by the Maximal Eigenvalue Test. That is, the time 
series share a common stochastic trend and will grow proportionally and move together in the long run. Given that LGDP, LEXPORTS, LIMPORTS, LEXCH, LPUB, LPRIV, LTOT, LHUM, LLABOUR and LEF are integrated of order one based on the Unit Root Tests results, the next step is to determine whether any combinations of the variables are integrated. The long-run static model is estimated (see, Table 5.3) and the residual of the long-run static model is tested as to whether it is stationary. The results indicate and confirm the co-integration existence between the series. The residual is integrated of order zero therefore can be used in the dynamic equation as an error correction mechanism.

\section{$5.4 \quad$ Regression Results}

Table 5.3 presents the estimation results of the static model, which represent the long-run model. This gives long-run relationship between economic growth and public and private investment, exports, imports, labor, human capital, economic freedom, real exchange rate and terms of trade. In addition to these variables the model included two dummy variables; dummy one captures the pre-independence period (1970-1989) and post-independence period (1990-2005), while dummy two capture the period from 1996-2002 when the Namibian dollar experienced persistent drastic depreciation.

The estimation indicates and confirms that public and private investment, exports, imports, economic freedom, labor and human capital have long run positive impact on economic growth. The estimated magnitude of these impacts is numerically quite large, with all the variables in log form, the coefficients can be interpreted as elasticities. The above variables are all significant at 5 percent significant level. This supports the theoretical and empirical findings. To determine whether public investment is more effective then private investment the two coefficients were compared based on the format adopted by Khan and Reinhard (1990). Looking at the regression result in Table 5.3, it indicates that private investment coefficient is larger than public investment coefficient. Therefore it can be concluded that private investment is more effective in the long run then public investment. The goodness of fit of the model is good, because, the R-squared and R-squared adjusted are 99.60 and 99.42 percent respectively.

Table 5.3: The Estimated Long-Run Static Model

\begin{tabular}{|l|c|c|c|c|}
\hline Variable & Coefficient & Std. Error & t-Statistic & Prob. \\
\hline LEXPORTS & 0.121 & 0.051 & 2.389 & 0.016 \\
\hline LEXCH & -0.066 & 0.019 & -3.453 & 0.002 \\
\hline LEF & 0.279 & 0.095 & 2.946 & 0.007 \\
\hline LHUM & 0.751 & 0.195 & 3.849 & 0.001 \\
\hline LIMPORTS & 0.203 & 0.104 & 1.949 & 0.063 \\
\hline LLABOUR & 0.435 & 0.141 & 3.082 & 0.005 \\
\hline LTOT & -0.052 & 0.025 & -2.080 & 0.014 \\
\hline LPUB & 0.076 & 0.027 & 2.767 & 0.011 \\
\hline LPRIV & 0.103 & 0.022 & 3.767 & 0.001 \\
\hline DUMMY1 & -0.111 & 0.035 & -3.112 & 0.005 \\
\hline DUMMY2 & 0.292 & 0.024 & 2.352 & 0.009 \\
\hline C & -9.333 & 2.417 & -3.861 & 0.001 \\
\hline R-squared & 0.996 & \multicolumn{2}{|c|}{ Mean dependent var } & 8.708 \\
\hline Adjusted R-squared & 0.994 & \multicolumn{2}{|c|}{ S.D. dependent var } & 0.339 \\
\hline S.E. of regression & 0.026 & \multicolumn{2}{|l|}{ Akaike info criterion } & -4.219 \\
\hline Sum squared resid & 0.016 & \multicolumn{2}{|c|}{ Schwarz criterion } & -3.692 \\
\hline
\end{tabular}




\begin{tabular}{|l|c|l|c|}
\hline Log likelihood & 87.953 & F-statistic & 549.297 \\
\hline Durbin-Watson stat & 2.096 & Prob(F-statistic) & 0.000 \\
\hline
\end{tabular}

Sources: Eview 5.1 Results

The diagnostic tests including Breusch-Godfrey serial correlation LM test, ARCH test, JacqueBera-normality test and Ramsey RESET specification test reveals no signs of misspecification, All the tests revealed that the model has the desired econometric properties, namely, it has a correct functional form and the model's residuals are serially uncorrelated, normally distributed and homoskedastic. Therefore, the results reported are valid for reliable for interpretation.

The ECM was estimated and the variables with insignificant lags were removed from the model. This resulted in the ECM presented in Table 5.4. The estimation indicates and confirms that public and private investments are significant and have positive short-run impact on economic growth. Public investment in the first lag has a negative coefficient and is statistically significant at 5 percent significant level. This implies that public investment in first lag have adverse short run impact on economic growth. Therefore one cannot rule out that public investment crowd out private investment in the short run. And most importantly, this could also suggest that it probably takes considerable duration for public investment to make short-run positive impact on economic growth. Further, public investments in second and third lags have both positive coefficients and are statistically significant at 10 percent and 5 percent significant levels. This infers that public investment in second and third lags has short run positive impact on economic growth.

The short run coefficients estimates for private investment in first and third lag are positive and statistically significant at 5 percent significant level. This implies that public investment exert a short run positive effect on economic growth, thus, supporting theoretical and empirical findings. The findings pertaining to public and private investment concur with conclusions that John and Ndeutalala (2003), Ahmed (2003) and Nazmi and Ramirez (1997) draw from their studies. It also sharply concur with the conclusion that Khan and Reinhard (1990) draw from analyzing a cross-section sample of 24 developing countries which concluded that private investment plays a much larger, and thus more important, role in the growth process then does public investment.

Other important variables included in the model such as exports in first and second lag has positive coefficient and statistically significant at 5 percent significant level. This confirms that exports drive short run economic growth. This supports the findings by Voxi (1999) in a study on export and economic growth in Namibia. Human capital in second and third lag and economic freedom in its first, second and third lag have emerge positive and significant at 5 percent significant level. This confirms the findings by Jacob (2004) on a cross-country study on developing countries including Namibia. Labour in first and second lag is positive and significant at 5 percent significant level.

Table 5.4: The Estimated Dynamic Error Correction Model

\begin{tabular}{|l|c|c|c|c|}
\hline Variable & Coefficient & Std. Error & t-Statistic & Prob. \\
\hline C & 0.004 & 0.013 & 0.322 & 0.757 \\
\hline DLEXPORTS(-1) & 1.383 & 0.307 & 4.497 & 0.003 \\
\hline DLEXPORTS(-2) & 1.395 & 0.325 & 4.288 & 0.004 \\
\hline DLHUM(-2) & 2.914 & 0.640 & 4.556 & 0.003 \\
\hline DLHUM(-3) & 4.105 & 0.948 & 4.332 & 0.003 \\
\hline DLIMPORTS(-1) & -1.701 & 0.411 & -4.143 & 0.004 \\
\hline DLIMPORTS(-2) & 0.609 & 0.180 & 3.378 & 0.012 \\
\hline DLIMPORTS(-3) & 0.638 & 0.146 & 4.386 & 0.003 \\
\hline
\end{tabular}




\begin{tabular}{|c|c|c|c|c|}
\hline DLTOT(-2) & -0.844 & 0.168 & -5.024 & 0.002 \\
\hline DLTOT(-3) & -0.656 & 0.188 & -4.964 & 0.010 \\
\hline $\operatorname{DLEF}(-1)$ & 1.403 & 0.359 & 3.910 & 0.006 \\
\hline $\operatorname{DLEF}(-2)$ & 1.374 & 0.333 & 4.122 & 0.005 \\
\hline DLEF(-3) & 0.480 & 0.159 & 3.014 & 0.020 \\
\hline DLPUB(-1) & -0.057 & 0.023 & -2.505 & 0.041 \\
\hline DLPUB(-2) & 0.076 & 0.035 & 2.174 & 0.066 \\
\hline DLPUB(-3) & 0.239 & 0.058 & 4.123 & 0.004 \\
\hline DLPRIV(-1) & 0.243 & 0.064 & 3.789 & 0.007 \\
\hline DLPRIV(-3) & 0.196 & 0.050 & 3.936 & 0.006 \\
\hline DLLABOUR(-1) & 1.351 & 0.413 & 3.272 & 0.014 \\
\hline DLLABOUR(-2) & 1.530 & 0.370 & 4.140 & 0.004 \\
\hline DLEXCH(-1) & -0.333 & 0.112 & -2.985 & 0.020 \\
\hline DLEXCH(-3) & -0.161 & 0.079 & -2.039 & 0.081 \\
\hline DUMMY2 & 0.027 & 0.013 & 2.000 & 0.086 \\
\hline DUMMY1 & -0.038 & 0.019 & -1.971 & 0.089 \\
\hline ECM $(-1)$ & -0.269 & 0.097 & -2.770 & 0.028 \\
\hline R-squared & 0.914 & \multicolumn{2}{|c|}{ Mean dependent var } & 0.033 \\
\hline Adjusted R-squared & 0.890 & \multicolumn{2}{|c|}{ S.D. dependent var } & 0.033 \\
\hline S.E. of regression & 0.020 & \multicolumn{2}{|c|}{ Akaike info criterion } & -4.916 \\
\hline Sum squared resid & 0.003 & \multicolumn{2}{|c|}{ Schwarz criterion } & -3.771 \\
\hline Log likelihood & 103.663 & \multicolumn{2}{|l|}{ F-statistic } & 235.104 \\
\hline Durbin-Watson stat & 2.327 & \multicolumn{2}{|c|}{ Prob(F-statistic) } & 0.000 \\
\hline
\end{tabular}

Sources: Eview 5.1 Results

However, imports in first and second lag are negative in contrast to imports in third lag which is positive. For the former it denotes that imports have negative impact on short run economic growth which is contradicting trade theory and empirical findings. And for the latter it implies positive impact on short run economic growth concurring with trade theory and empirical findings. Terms of trade in second and third lag and real exchange rate in its first and third lag exert negative impact on economic growth. The ECM estimated coefficient is estimated at -0.27 and it is statistically significant at 5 percent significant level, it has the correct sign and therefore suggests that any shock which diverge the economy from the steady state can converge to the long-run equilibrium path approximately in one year.

In conclusion the goodness of the model is good given that the R-square and R-square adjusted is 91.41 percent and 88.96 percent respectively (see, Table 5.4). The diagnostic tests of the model reveal that the model does not suffer from misspecification. The robustness of the model has been confirmed by several diagnostic tests such as Breusch-Godfrey serial correlation LM test, ARCH test, Jacque-Bera normality test and Ramsey RESET specification test. All the tests revealed that the model has the desired econometric properties, namely, it has a correct functional form and the model's residuals are serially uncorrelated, normally distributed and homoskedastic. Therefore, the results reported are valid for reliable interpretation. 


\subsection{Summary of Findings, Recommendations and Conclusion}

\subsection{Summary of Findings}

The study main objective is to improve the understanding of the impact of private and public investment on economic growth and point to policy measures aimed at further strengthening economic growth in Namibia. In this regard, the study analyzed the impact of public and private investment on economic growth in Namibia. The methodology adopted is the new neo-classical growth model of Solow utilizing the error correction model (ECM). The model is implemented empirically utilized macroeconomic data for Namibia from 1970 to 2005 period. The empirical implementation follow a co-integration approach that makes use of long-run and short-run analysis. The unit analysis tests conducted confirm that both variables are stationary in first difference and the co-integration tests also confirm the existence of long term relationship between the variables. The findings of the study concluded that there exist a short-run and longrun relationship between public and private investment and economic growth in Namibia. This implies that public and private investment impact positively economic growth in the short and long run process. In addition it confirms that private investment is more effective in the long run then public investment.

Another main finding of the study confirms the existing empirical findings which are consistent by inferring a positive relationship between exports, imports, economic freedom, human capital, labor and economic growth. It reaffirms recent studies undertaken that exports, labor, imports, economic freedom, human capital have a positive impact on economic growth in Namibia both in the short and long run perspective. In addition the study also infers a negative relationship between real exchange rate and terms of trade and economic growth in the short and long-run process. It document that real exchange rate and term of trade exert adverse impact on economic growth both in short and long term process.

\subsection{Recommendations}

The empirical results of the study have useful implication for Namibia. Thus an important implication for policy is that public and private investment, exports, imports, economic freedom, labor and human capital are major determinants of economic growth in Namibia. Therefore the Namibian authority must exert and placed emphasis on these seven variables in efforts to enhance and stimulate economic growth in Namibia.

\subsection{Conclusion}

The impact of public and private investment on economic growth is a long standing issue in macroeconomics and development economics. The emphasis and position of this paper is that both public and private investment plays an important role in effecting economic growth. Public investment plays a dual role in the economy. Public investments in particular in infrastructure raises the profitability of private production and encourage private investment, while noninfrastructure projects in areas where the public sector competes with private firms may have the opposite effect. Most importantly private investment vigorously plays a catalytic role in the economy. It is through private investment that production is expanded and the generation of new employment opportunities is realized. It creates and increase income for the economy. In turn this generate revenue that governments needs to expand access to health, education and public investment in infrastructure development and services and so assist improve the productive ca pacityof the economy.

\section{References}

Argimon, I., J. Gonzalez-Paramo and J. Roldan, 1995. Does Public Investment Crowd-out Private Investment? Evidence from a Panel of 14 Countries. Washington D.C., International Institute of Public Finance. 
Aschauer, David A., 1989a. Is Public Expenditure Productive?. Journal of Monetary Economics, Vol. 23: 177-200.

Aschauer, David A., 1989b. Does Public Capital Crowd Out Private Capital?, Journal of Monetary Economics, Vol. 24: 171 -188.

Barro, Robert J., 1990. Government Spending in a Simple Model of Endogenous Growth. Journal of Political Economy, Vol. 98: 100-105.

Barro, Robert J., 1989. A Cross Country Study of Growth, Saving and Government. Working Paper No. 2855. National Bureau of Economic Research, 1050.

Berndt, E., and B. Hansson, 1992. Measuring the Contribution of Public Infrastructure Capital in Sweden, Scandinavian Journal of Economics, Vol. 94: 151-168.

Canning, D., Fay, M., and Perotti, R., 1994. Infrastructure and growth, In Bsaldassarri, M., Paganetto, M., Phelps, E.S. (Eds.), International Differences in Growth Rates. St. Martin's Press, New York.

Cardosa, E., 1993. Private Investment in Latin America, Economic Development and Cultural Change, Vol. 41: 833-848.

Cengiz Cihan and Dilip Dutta, 2005. Trade Liberalization and Economic Growth in Turkey, An Empirical Model of Endogenous Growth Analysis, Journal of Economics of Planning, Vol. 28(23):147-167.

Charles R. Hulten and George E. Peterson, 1984. The Public Capital Stock: Needs, Trends and Performance, The American Economic Review, Vol. 74(2):166-173.

Chenery, Hollis, and M. Strout (1966), “Foreign Assistance and Economic Development”, American Economic Review, Vol. 56, No. 4, pp. 679-733.

Devajaran, Shantayanan, Vinaya Swaroop and Heng-fu Zou, 1996. The composition of public expenditure and economic growth", Journal of Monetary Economics, Vol. 37(2): 313-344.

Easterly, William and Sergio Rebelo 1993. Fiscal Policy and Economic Growth, Journal of Monetary Economics, Vol. 32:417-458

Easterly William, Carlos A. Rodriguez and Klaus Schmidt-Hebbel, editors, 1994. Public Sector

Deficits and Macroeconomic Performance. Washington, D.C., World Bank and Oxford University Press.

Eberts, Randal I. W., 1986. Estimating the Contribution of Urban Public Infrastructure to Regional Growth. Working Paper No. 86. Cleveland, Federal Reserve Bank of Cleveland. Engle, R.F. and C.W.J. Granger, 1987. "Cointegration and Error Correction: Representation, Estimation and Testing", Econometrica, Vol. 55:251-276.

Erenburg, S.J., 1993. The real effects of public investment on private investment", Journal of Applied Economics, Vol. 25:831-837.

Fan, S., Jitsuchon, and N. Methakunnavut, 2004. Rural Infrastructure Development and Poverty Reduction in Rural Thailand. Project Report submitted to ADB by IFPRI and TDRI.

Holtz-Eakin, Douglas and Amy Ellen Schwartz, 1995. Spatial Productivity Spillovers from Public Infrastructure: Evidence from State High Ways, International Tax and Public Finance, Vol.2(3):459-468.

Jacob Zipfel, (2004), Determinants of Economic Growth". (October 29, 2004), Florida State University D-Scholarship Repository, Article No. 20.

<http://dscholarship.lib.fsu.edu/undergrad/20 > Accessed: 12 February 2007.

John, Ashipala and Ndeutalala Haimbodi, 2003. The impact of public investment on economic growth in Namibia, Working Paper No. 88, Windhoek, Namibia Economic Policy Research Unit (NEPRU).

Khan, M. S. and Reinhart, C., 1990. Private investment and economic growth in developing countries, World Development, Vol. 18(1):19-27.

Luis Serven, 1996. Does Public Capital Crowd Out Private Capital? Evidence from India, Policy Research Working Paper, No.1613, Washington D.C, World Bank, Policy Research Department, Macroeconomics and Growth Division.

Macmillan, W. and D. Smyth, 1994. A Multivariate Time Series Analysis of the United State Aggregated Production Function, Empirical Economics, Vol. 19:659-673. 
Munnell, Alicia, 1992. Infrastructure Investment and Economic Growth, Journal of Economic Perspectives, Vol. 6(4):189-98.

Munnell, Alicia H., 1990. How Does Public Infrastructure Affect Regional Economic

Performance, in Alicia H. Munnell, (ed.), Is There a Shortfall in Public Capital Investment? ,

Boston: Federal Reserve Bank of Boston, pp. 69-103.

Munnell, Alicia, 1990a. Why has Productivity Growth Declined?, New England Economic

Review, pp. 3-23.

Mustafa Ismihan, Kivilcim Metin-Ozcan and Aysit Tansel, 2002. Macroeconomic Instability, Capital Accumulation and Growth", The Case of Turkey 1963-

1999, <http://www.bilkent.edu.tr/ economics/papers/02- 05\%20DP\%20Kivilcim\%20Metin.pdf

$>$, Accessed 02 February 2006.

Nazmi, Nader and Miguel D. Ramirez, 1997. Public and private investment and economic growth in Mexico, Journal of Contemporary Economic Policy, Vol. 15(1):65-75.

North, Douglass C., 1990. Institutions, Institutional change, and Economic Performance, Cambridge University Press, New York.

Pereira, A. M., 2000. Is all public capital created equal?, Review of Economics and Statistics, Vol. 82(3):513-518.

Pereira, A. M., 2001a. On the Effects of Public Investment on Private Investment: What Crowds in What, Public Finance Review, Vol. 29(1):3-25.

Pereira, A. M., 2001b. Public Investment and Private Sector Performance- International evidence, Public Finance and Management, Vo. 1(2):261-277.

Ram, Rati, 1978. Export and Economic Growth, Developing and Cultural Change, Vol. 33:415425.

Ramirez, M. D. (1996), "Public and Private Investment in Mexico and Chile: An Empirical Test of the Complementarities Hypothesis", American Economic Journal, Vol. 24(4):301-320.

Ramirez, M. D., 1998. Does public investment enhance productivity growth in Mexico? A cointegration analysis, Eastern Economic Journal, Vol. 24(1):63-82.

Ramirez, M. D., 2000. The Impact of Public Investment on Private Investment Spending in Latin America: 1980-95", Atlantic Economic Journal, Vol. 28(2):210-26.

Ramirez, Miguel D. and Nader Nazmi, 2003. Public Investment and Economic Growth in Latin America: An Empirical Test “, Review of Development Economics, Vol. 7(1):115-126.

Sanchez-Robles B., 1998. Infrastructure Investment and Growth: Some Empirical Evidence”, Contemporary Economic Policy, Vol.16:98-108.

Tatom, John, May/June 1991. Public Capital and Private Sector Performance, Federal Reserve Bank of St. Louis Review, Vol. 73:3-15. J. A., 1991a. Public Capital and Private Sector Performance, Federal Reserve Bank of St. Louis Review, May/ June 1991, pp 3-15.

Tatom, J. A, 1991b. Should Government Spending on Capital Goods Be Raised? Federal Reserve Bank of St. Louis Review, March/ April 1991, pp3-15.

Tatom J.A., 1993a. Paved with Good Intentions; the Mythical National Infrastructure Crisis, Policy Analysis, Cato Institute.

Tatom J. A., 1993b. The Spurious Effect of Public Capital Formation on Private Sector Productivity," Policy Studies Journal, Vol. 21:391-395.

Voxi Heinrich Amavilah, (1999). Export and Economic Growth in Namibia, Phoenix, AZ 85069-8061 USA, <http://129.3.20.41/eps/dev/papers/0307/0307004.pdf> Accessed: 13 February 2006. 